\title{
RESEARCH BASED LEARNING IN HIGHER EDUCATION: A REVIEW OF LITERATURE
}

\author{
María Helen Camacho ${ }^{1}$, Martin Valcke ${ }^{2}$, Katherine Chiluiza ${ }^{3}$ \\ ${ }^{1}$ Ghent University/Escuela Superior Politécnica del Litoral (ECUADOR) \\ ${ }^{2}$ Ghent University (BELGIUM) \\ ${ }^{3}$ Escuela Superior Politécnica del Litoral (ECUADOR)
}

\begin{abstract}
Background: Teaching and learning in a university setting are distinctive from other types of Higher Education, due to its direct relationship with research. The increasing need to integrate teaching and research in Higher Education has led academics to incorporate authentic research experiences in their classes. This specific teaching-research nexus, labeled as Research-based learning (RBL) is designed around inquiry activities stimulating students to engage in real-life research by conducting their own experiments.
\end{abstract}

Purpose: There is gap in the literature when it comes to reviews that focus on RBL in Higher Education, particularly with a focus on the Engineering and Science domain. In our literature review analysis, we focus on: (1) students' research skills as developed by the RBL context, (2) the nature of Engineering and Science programs/courses that have adopted RBL approaches, (3) the impact of the RBL approach on students, (4) the key research variables included and the research methods used, (5) and the amount of time spent in RBL experiences.

Method: A systematic review of the literature was carried out, based on screening articles in the Web of Science and adopting the following inclusion criteria: (1) peer-reviewed journal or proceeding articles from 2000 to 2016 written in the English language, (2) related to RBL empirical work, (3) focused on students as participants, (4) carried out in Engineering and Science class settings, (5) set up in Higher Education contexts. Using the key search descriptors "research based learning", "research based", and "teaching research nexus", initially 2492 articles were identified but only 33 fully met the criteria. To broaden the available dataset, we identified further other 17 additional articles building on the reference lists of the selected studies. This increased the number of articles to be analyzed to 50. Next, the articles were analyzed and synthesized following the above analysis categories.

Conclusions: The study presented a first overview of the available literature in terms of RBL within Engineering and Science fields in Higher Education. The 50 selected studies helped developing an indepth picture of the latest RBL developments. The results show Chemistry and Biology were the dominant courses implementing RBL; usually in lab settings. The most emphasized research skills were "analyzing data", "conducting research" and "communicating results". "Interest in research or the subject" and "scientific/critical thinking and attitudes towards research" were the key dependent variables. Most RBL interventions reported positive results, building on quantitative methods and lasting 1 to 2 semesters as the typical time frame. The review results put forward a sound base to develop decisions about the implementation of $\mathrm{RBL}$ in future higher education settings. At the same time, they reflect gaps to be addressed: (1) empirical studies that comprise a more comprehensive study of the research cycle, (2) research designs to study the impact of RBL that include mediating or moderating variables such as motivation, self-efficacy or engagement,(3) the use of reliable and validated research instruments.

Keywords: engineering, research-based learning, higher education, systematic review

\section{INTRODUCTION}

Teaching and learning in university education are different from other types of Higher Education due to its direct relationship with research. This teaching-research nexus (TRN) builds on a strong academic tradition. It is broadly recognized that teaching and research are inseparable entities and that they are aligned with the purpose of universities to develop and distribute knowledge, as manifested in the 
Magna Charta Universitatum [1]. Although this TRN is strongly emphasized, the educational reality shows a somewhat different picture, especially among teaching staff who hardly focus on research as part of their profession and due to tensions between resources allocated to either teaching and/or research [2].

In recent years, attempts can be observed to integrate teaching and research in Higher Education [3], resulting in stronger student engagement in research and their incorporation in the academic community [4]. As a TRN strategy, Research Based Learning (RBL) RBL highlights students undertaking inquiry-based learning [5] . It can boost learning performance when incorporated in courses and programs. This can be achieved by teaching research methods and techniques openly, including small-scale research activities as part of the assignments, engaging students in departmental research projects and promoting a research spirit [6]. When students are introduced to research methods through RBL strategies, they acquire skills needed to conduct research independently and disseminate their products [7].

Even though there is a clear connection between teaching and research, it is relevant to explore what truly happens in practice [8] within Engineering and Science class settings.

Empirical research about RBL is scarce and literature reviews are lacking, especially in the engineering domain. In the research literature, only review studies from the medical field could be traced. A first study analysis revealed how students' engagement in research led to positive responses towards research and the study of the medical domain [9]. Another study, building on experiences in Thailand, revealed that RBL influences several variables, including knowledge, discovery and skills such as thinking, achievement, researcher nature, problem solving and inquiry [10].

In this study we address the gap in the literature and develop a systematic literature review about Research Based Learning in Higher education with a focus on Engineering and Science contexts. Our main aims are to provide a current state-of-the-art of empirical work regarding RBL. This work is organized as follows. We first introduce the methodology adopted to develop the review study by focusing on inclusion and exclusion criteria and the resulting analysis of a final selected of research articles. Next, we describe the results and present a discussion that also emphasizes limitations of the current approach and conclusions that especially emphasize directions for future research.

\section{METHOD}

To conduct this review, the five stage framework of [11] was adopted to follow a rigorous and transparent method to map the target research that increases reliability of the study findings. The framework consists of five stages, explained below.

\subsection{Stage 1: Identifying the initial research questions}

The focus of our review was the exploration of key elements of Research Based Learning that have an impact on students' research skills. For this purpose, we pose the following initial research questions: Q1. What research step in the research cycle is stressed and what research skills are being developed in RBL set ups within the engineering and science education domain

Q2. Which Engineering and Science programs have adopted RBL approaches?

Q3. What have been the outcomes of the studies?

Q4: Which variables have been identified and what data collection methods have been used?

Q5: How much time have students been involved in the RBL experience?

\section{2 Stage 2: Identifying relevant studies}

The selection process for the present review article started October 2016 and lasted about 3 weeks. The "Web of Science" was used as the key source to identify peer-reviewed literature from journals and proceedings within the Engineering and Science domain. Only English language publications were considered. The search key terms used in title and content fields were "research based learning", "research based", "teaching research nexus" or research teaching nexus" As a time frame we considered the period 2000-2016.

\subsection{Stage 3: Study Selection}


Using the key search descriptors, 2492 articles could be identified. A review of the abstracts revealthat a great number of articles were irrelevant. Other articles were removed from the search as they were duplicates or access was restricted.

Table1: Inclusion and exclusion criteria

\begin{tabular}{|c|c|c|}
\hline Criterion & Inclusion & Exclusion \\
\hline Topic & RBL as defined by [12] & $\begin{array}{l}\text { research based activities in } \\
\text { non-educational contexts } \\
\text { non-RBL approaches }\end{array}$ \\
\hline Educational level & $\begin{array}{l}\text { Higher } \\
\text { Undergraduate/Graduate }\end{array}$ & $\begin{array}{l}\text { other settings such as primary } \\
\text { or high school or not specified }\end{array}$ \\
\hline Participants & Students & faculty, managerial staff \\
\hline Study Focus & Empirical studies & $\begin{array}{l}\text { Review of research, RBL } \\
\text { design, non-empirical studies }\end{array}$ \\
\hline Other & N/A & $\begin{array}{llll}\begin{array}{l}\text { Duplicate } \\
\text { accessible }\end{array} & \text { articles } & \text { or } & \text { not }\end{array}$ \\
\hline
\end{tabular}

Guided by the inclusion and exclusion criteria explained in Table 1, only 33 studies fit all the criteria and were considered relevant to answer the research questions. To broaden the available dataset, we identified further related publications, building on the reference lists of the selected studies. This resulted in 17 additional articles meeting the inclusion and exclusion criteria detailed below. This increased the number of articles to be analyzed to 50 . Figure 1 illustrates the process of article selection.

Studies excluded by:

Topic $(n=2356)$

Educational Level $(n=26)$

Participants $(n=54)$

Study focus (15)

Other $=(n=8)$
Studies identified through database searching:

$$
n=2492
$$

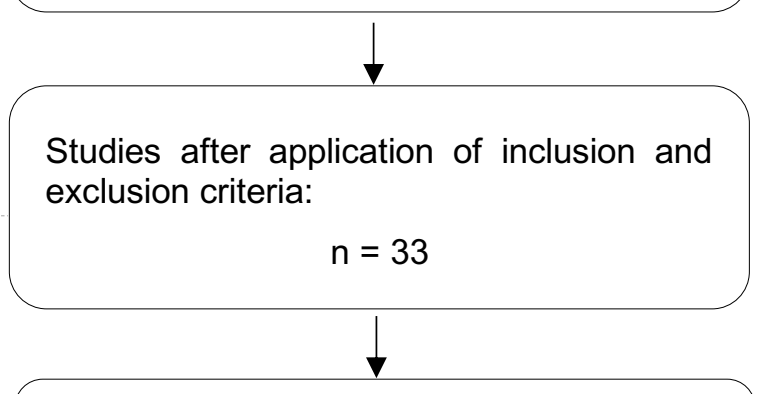

Final studies included in review:

$$
n=50
$$

Criteria (Keywords, time frame, type of article, language, peer reviewed)
Studies included based on new search of references in reviews of literature

$$
(n=17)
$$

Fig 1. Article selection process.

Due to space constraints, we do not give a detailed descriptive overview of these 50 studies. The reader can find at the end of this article the specific list of references (see section 7).

\subsection{Stage 4: Charting the data}

At this stage, summaries of each selected article were developed focusing on country, year of publication, sample size, type of RBL activity within a research cycle for engineering as proposed by [13], nature of the program or course, research variables, research methods, RBL duration and measured outcomes. A table summarizing this analytical perspective on the 50 articles can be obtained from the first author of this contribution, 


\subsection{Stage 5: Collating, summarizing and reporting results}

During this fifth stage, we pulled together the analytical information resulting from the stage 4 and developed a synthesis as reported in the next section.

\section{RESULTS}

The literature review reflects studies set up in six different countries. Of these, 44 studies were conducted in the United States; single studies were reported from China, Australia, Germany, Canada, the United Arab Emirates and the United Kingdom. There is a notable absence of literature from South America, Asia and Africa.

Regarding the RBL focus on steps in the engineering/science research cycle, most studies focus on multiple steps. Pulling the studies together, all stages are being covered. Most studies center on research activities related to collecting, analyzing and interpreting data $(n=32)$, followed implementing research designs $(n=24)$, and a focus on communicating research findings $(n=23)$.

Regarding research methodologies, most studies adopt a quantitative approach $(n=24)$, followed by mixed studies $(n=15)$ and qualitative approaches $(n=11)$. In terms of sample size, 32 studies involve 6 to 109 students, followed by 9 studies involving 114 to 500 and 3 studies building on a sample size ranging from 640 to 800 students. Only one study is based on a smaller sample. Five studies did not specify the sample size.

\subsection{Discussion in relation to the research questions}

Q1. What steps in the research cycle are stressed and what research skills are developed in RBL set ups within the engineering and science education domain?

Table 2: Specification of research skills and research cycle steps in the studies

\begin{tabular}{|l|l|l|}
\hline Research cycle phase & Research skill & Total \\
\hline $\begin{array}{l}\text { Discover requirements, state initial research problems } \\
\text { and questions }\end{array}$ & Identify a research problem & 7 \\
\hline Immerse in theory & $\begin{array}{l}\text { Search for literature, write } \\
\text { bibliographical citations }\end{array}$ & 18 \\
\hline Generate research questions/hypothesis & $\begin{array}{l}\text { Generate research questions and } \\
\text { hypothesis }\end{array}$ & 12 \\
\hline Develop research methodology & $\begin{array}{l}\text { Select research methods, set up } \\
\text { studies }\end{array}$ & 15 \\
\hline Conduct research & $\begin{array}{l}\text { Carry out experiments or research } \\
\text { set-ups, collect data }\end{array}$ & 24 \\
\hline Analyze and interpret data & $\begin{array}{l}\text { Analyze data and interpret } \\
\text { findings }\end{array}$ & 32 \\
\hline Implement findings & $\begin{array}{l}\text { Report findings in papers, posters } \\
\text { and new research proposals }\end{array}$ & 23 \\
\hline
\end{tabular}

Table 2 shows the different research skills and research cycle phases emphasized the most in the studies. We based our analysis on the phases of the research cycle suggested by [13] where students can participate in selected phases or in the whole process. It starts with a knowledge gap perceived by the student, followed by an initial question or problem not yet resolved which leads to stating objectives and searching for relevant literature. Then the methods are built up in dependence on the research questions generated, the experiment is performed, results are analyzed, implemented and/or disseminated. From the results we can state that the main aim is to encourage students to develop skills related to analyzing data and interpreting findings as well as performing their own experiments and communicating their findings through a scientific paper or research report. This emphasis on conducting research is supported by the ideas of [63] who labels it as a critical issue for the professional progress of science students. Similarly the dissemination of research findings in a conference experience for instance, has been proved to add a varied range of skills and professional qualities to students who participate in such an authentic learning environment [64]. The possibility of being more actively involved in potential publications may encourage students to improve their academic writing, work harder and reach a broader audience [65]. 
As we may notice, some articles were counted more than once in each appropriate stage as they focused on several research skills. For this reason the sum of the counts for research skills does not equal the total number of papers.

\section{Q2. Which Engineering and Science programs have adopted RBL approaches?}

Chemistry is the field, which contains most of the selected studies $(n=26)$. The performance of chemical experiments allows students to increase appreciation and knowledge regarding subjectrelated issues. They use problem solving and critical thinking skills to propose novel results within the processes used in chemical research [66]. This is in line with [16] who state that instructional laboratories with a research-based orientation can not only impart scientific knowledge but also increase students' research expertise and confidence. Other dominant field is Biology $(n=14)$, followed by Engineering $(n=7)$, Physics $(n=4)$ and Environmental Sciences $(n=1)$. Some studies involve students from more than one program, for example a sample includes students from Chemistry, Physics and Biology majors. This is why; again the sum of the counts for Engineering and Science courses do not equal the total number of selected papers.

\section{Q3. What have been the results of the studies?}

The selected studies have been classified as positive, negative and mixed, being positive the most commonly found result $(n=29)$ followed by neutral $(n=13)$ and mixed $(n=8)$. The positive outcomes found in this review may be associated with the fact that classroom research experiences provide students with learning opportunities as well as benefits for faculty research programs [26].

No negative results are reported in this preliminary review study. We may infer that although expected empirical results were not fully achieved, there was some kind of contribution to the field

\section{Q4: Which variables and data collection methods have been used?}

Quantitative, qualitative and mixed methods have been used in the selected studies, being the quantitative the most used to measure achievement, academic performance and learning gains ( $\mathrm{n}=$ $24)$, followed by mixed $(n=11)$ and qualitative $(n=11)$.

Regarding the variables included in the studies, "research interest" is dominant in the list $(n=21)$. This conclusion may be rooted within a typology of RBL which focuses on students' research interests that is reflected in their research and learning interests [67]. This is also related to what [68] claim about the positive influence of undergraduate research practices on students' decisions to keep doing research. Research experiences have the capacity to encourage students' interest by providing them opportunities to explore the questions they generate. [69]. Similarly, "critical /scientific thinking" ( $n=$ 13) and "perceptions/attitudes/conception of research" $(n=13)$ are also found in a great number of studies followed by achievement $(n=12)$, confidence $(n=11)$, research skills $(n=11)$ and motivation $(n=8)$.

On the other hand, "problem solving" $(n=5)$ "self-efficacy" $(n=2)$ and "communication skills" $(n=4)$ are not commonly considered in the RBL interventions compiled in the selected studies.

Again, most studies involve more than one variable within the same experience; therefore the sum of the counts does not equal the total number of papers.

\section{Q5: How much time have students been involved in the RBL experience?}

The most usual time range in a large number of studies is from 1 to 2 semesters, usually in courses taught in a sequential order. This is followed by RBL experiences, which take more than 1 year, generally involving several cohorts from one or more programs. Only 2 studies were carried out in a period of 1 to 5 weeks as well as in 6 to 10 weeks. These courses were mostly at intensive masters' or doctorate level programs that are typically taught in shorter time. These findings support the fact that it is important to have realistic learning goals for undergraduates that participate in short-term research experiences. It may be doubtful that in a period shorter than 10 weeks students gain enough proficiency to become researchers. However, it is possible that students gain abilities to complete a small research project if frequently exposed to proper learning opportunities. [70]. 


\section{LIMITATIONS}

There are several limitations in the present work. Firstly, examining empirical studies from 2000 to 2016 may exclude important prior work from the sample. However, the lack of literature reviews concerning RBL in the given search period reflects that in general, there must be a limited number of studies published before 2000 . Therefore, we consider that focusing on the publications of the last 15 years is appropriate to answer in detail the proposed research questions.

Secondly, articles that did not include any of the selected key words in the title with abstracts that did not explain the context of an RBL empirical study clearly were missed. Similarly, articles that were directly related to the topic but not available because of restricted access could not be included.

\section{CONCLUSIONS}

This study reports findings regarding the existing literature in relation to Research Based Learning in Higher Education particularly within Engineering and Science fields. The selected studies provide a general idea of the developments carried out from 2000 to 2016.

The fact that more than half of the studies were published since 2010, suggests an increasing interest in disseminating the outcomes of incorporating RBL practices in Higher Education courses.

The literature found shows that there is a strong emphasis on the development of some students' research skills such as analyzing data, interpreting findings, conducting their own experiments and reporting their findings through research reports or papers. Chemistry is the field where more RBL experiences have taken place mainly in laboratory settings followed closely by Biological labs. In most studies "interest in research/interest in the subject" is considered as the key dependent variable and the most used time frame for RBL implementation is between 1 and 2 semesters.

This systematic review, however, has identified some weaknesses in the variables promoted in students in most RBL interventions. For instance, self-efficacy and problem solving were not consistently found in the cited literature.

To strengthen the future research in RBL, we suggest relying on a broader range of databases and consider other variables that also interplay meaningfully in the integration of teaching and research.

\section{ACKNOWLEDGEMENTS}

This research was supported by the Ecuadorian Government through SENESCYT (Secretary of Higher Education, Science, Technology and Innovation) and IFTH (Institute to promote human talent) We thank the authorities and academic staff from the Escuela Superior Politécnica del Litoral who were involved in the study and provided insights that greatly assisted the research.

We would also like to show our gratitude to professors from the research committee at the Department of Educational Studies at Ghent University for their comments on this work.

\section{REFERENCES}

[1] A. Oosterlinck, "Observatory Magna Charta Universitatum," Accountability, the Magna Charta Universitatum and the Bologna Declaration, 2013. [Online]. Available: https://www.google.com.ec/search?q=Magna+Charta+Universitatum+(Oosterlinck\%2C+2013\& oq=Magna+Charta+Universitatum+(Oosterlinck\%2C+2013\&aqs=chrome..69i57.633j0j1\&sourc eid=chrome\&ie=UTF-8. [Accessed: 06-Jan-2017].

[2] W. E. Boyd, M. O'Reilly, K. Rendell, S. Rowe, E. Wilson, K. Dimmock, W. Boyd, E. M. Nuske, J. R. Edelheim, D. J. Bucher, and K. Fisher, "Friday Is My Research Day': Chance, Time and Desire in the Search for the Teaching-Research Nexus in the Life of a University Teacher," $J$. Univ. Teach. Learn. Pract., vol. 9, no. 2, pp. 1-17, Nov. 2012.

[3] A. Brew, "Imperatives and challenges in integrating teaching and research," 2010.

[4] J. Blomster, S. Venn, and V. Virtanen, "Towards Developing a Common Conception of Research-Based Teaching and Learning in an Academic Community," High. Educ. Stud., vol. 4, no. 4, pp. 62-75, 2014.

[5] R. Griffiths, "Knowledge production and the research-teaching nexus: The case of the built environment disciplines," Stud. High. Educ., vol. 29, no. 6, pp. 709-726, 2004.

[6] L. Nuchwana, "How to Link Teaching and Research to Enhance Students' Learning Outcomes: Thai University Experience," Procedia - Soc. Behav. Sci., vol. 69, pp. 213-219, Dec. 2012. 
[8] M. Tight, "Examining the research/teaching nexus," Eur. J. High. Educ., vol. 6, no. 4, pp. 1-19, Sep. 2016.

[9] C. Naing, V. N. Wai, J. Durham, M. A. Whittaker, N. N. Win, K. Aung, and J. W. Mak, "A Systematic Review and Meta-Analysis of Medical Students' Perspectives on the Engagement in Research.," Medicine (Baltimore)., vol. 94, no. 28, p. e1089, Jul. 2015.

[10] S. Srikoon, J. Samranjai, and J. Wattanathorn, "Research synthesis of Research-based learning for Education in Thailand," Procedia - Soc. Behav. Sci., pp. 914-917, 2013.

[11] H. Arksey and L. O'Malley, "Scoping studies: towards a methodological framework," Int. J. Soc. Res. Methodol., vol. 8, no. 1, pp. 19-32, Feb. 2005.

[12] M. Healey and A. Jenkins, "LINKING DISCIPLINE-BASED RESEARCH AND TEACHING THROUGH MAINSTREAMING UNDERGRADUATE RESEARCH AND INQUIRY," 2009.

[13] T. Jungmann and P. Ossenberg, "Research workshop in engineering education-Draft of new learning," in 2014 IEEE Global Engineering Education Conference (EDUCON), 2014, pp. 8387.

\section{References incorporated in the literature review analysis}

[7] D. Christe, A. Shah, J. Bhatt, and L. Powell, "Raising interest in STEM education: A researchbased learning framework," Emerg. Trends, 2015.

[14] A. A. Fuller, "Combinatorial Solid-Phase Synthesis of Aromatic Oligoamides: A ResearchBased Laboratory Module for Undergraduate Organic Chemistry," J. Chem. Educ., vol. 93, no. 5, pp. 953-957, May 2016.

[15] J. Ma, "Incorporating Research-Based Problems from the Primary Literature into a Large-Scale Organic Structure Analysis Course," J. Chem. Educ., vol. 92, no. 12, pp. 2176-2181, Dec. 2015.

[16] C. Gray, C. W. Price, C. T. Lee, A. H. Dewald, M. A. Cline, C. E. McAnany, L. Columbus, and C. Mura, "Known structure, unknown function: An inquiry-based undergraduate biochemistry laboratory course," Biochem. Mol. Biol. Educ., vol. 43, no. 4, pp. 245-262, Jul. 2015.

[17] R. Iyer, K. Smith, B. Kudrle, and A. Leon, "Detection and location of OP-degrading activity: a model to integrate education and research," N. Biotechnol., 2015.

[18] A. Kohnle, C. Baily, and A. Campbell, "Enhancing student learning of two-level quantum systems with interactive simulations," Am. J., 2015.

[19] W. L. Scott, R. E. Denton, K. A. Marrs, J. D. Durrant, J. G. Samaritoni, M. M. Abraham, S. P. Brown, J. M. Carnahan, L. G. Fischer, C. E. Glos, P. J. Sempsrott, and M. J. O'Donnell, "Distributed Drug Discovery: Advancing Chemical Education through Contextualized Combinatorial Solid-Phase Organic Laboratories," J. Chem. Educ., vol. 92, no. 5, pp. 819-826, May 2015.

[20] R. Gao, "Incorporating Students' Self-Designed, Research-Based Analytical Chemistry Projects into the Instrumentation Curriculum," J. Chem. Educ., vol. 92, no. 3, pp. 444-449, Mar. 2015.

[21] K. Winkelmann, M. Baloga, T. Marcinkowski, C. Giannoulis, G. Anquandah, and P. Cohen, "Improving Students' Inquiry Skills and Self-Efficacy through Research-Inspired Modules in the General Chemistry Laboratory," J. Chem. Educ., vol. 92, no. 2, pp. 247-255, Feb. 2015.

[22] S. Blume, N. Madanchi, S. Böhme, G. Posselt, S. Thiede, and C. Herrmann, "Die Lernfabrik Research-based Learning for Sustainable Production Engineering," in The 5th Conference on Learnng Factories 2015, 2015, vol. 32, pp. 126-131.

[23] J. H. Tomasik, D. LeCaptain, S. Murphy, M. Martin, R. M. Knight, M. A. Harke, R. Burke, K. Beck, and I. D. Acevedo-Polakovich, "Island Explorations: Discovering Effects of Environmental Research-Based Lab Activities on Analytical Chemistry Students," J. Chem. Educ., vol. 91, no. 11, pp. 1887-1894, Nov. 2014.

[24] M. D. Sharma, A. Mendez, I. M. Sefton, J. Khachan, H. A. and L. V N, S. M. D. and K. J. Richardson A, B. A. and A. S, M. S. and Z. X. Etkina E, S. J. I, H. E, W. B. A, K. J. G, F. J. L. and G. W. C, H. E. H, M. R, P. G, B. S. C, C. R. G. ed N. E, R. A. and R. W, M. A. and P. J. Mills D, Sharma M D, C. A. J. and J. W. F, and J. R. T. and S. K. A. Johnson D W, "Student evaluation of research projects in a first-year physics laboratory," Eur. J. Phys., vol. 35, no. 2, p. 25004, Mar. 2014.

[25] J. H. Tomasik, K. E. Cottone, M. T. Heethuis, and A. Mueller, "Development and Preliminary Impacts of the Implementation of an Authentic Research-Based Experiment in General Chemistry," J. Chem. Educ., vol. 90, no. 9, pp. 1155-1161, Sep. 2013.

[26] C. W. Miller, J. Hamel, K. D. Holmes, W. L. Helmey-Hartman, and D. Lopatto, "Extending Your Research Team: Learning Benefits When a Laboratory Partners with a Classroom," 
Bioscience, vol. 63, no. 9, pp. 754-762, Sep. 2013.

[27] A. Chase, D. Pakhira, and M. Stains, "Implementing Process-Oriented, Guided-Inquiry Learning for the First Time: Adaptations and Short-Term Impacts on Students' Attitude and Performance," J. Chem. Educ., vol. 90, no. 4, pp. 409-416, Apr. 2013.

[28] K. J. Parra, M. P. Osgood, and D. L. Pappas, "A research-based laboratory course designed to strengthen the research-teaching nexus," Biochem. Mol. Biol. Educ., vol. 38, no. 3, pp. 172179, May 2010.

[29] C. J. Brame, W. M. Pruitt, and L. C. Robinson, "A Molecular Genetics Laboratory Course Applying Bioinformatics and Cell Biology in the Context of Original Research," Cell Biol. Educ., vol. 7, no. 4, pp. 410-421, Dec. 2008.

[30] T. A. Newton, H. J. Tracy, and C. Prudenté, "A Research-Based Laboratory Course in Organic Chemistry," J. Chem. Educ., vol. 83, no. 12, p. 1844, Dec. 2006.

[31] M. Carnahan, K. Cox, J. Espinosa, R. Feaster, R. Hirsch, A. Lam, S. Roller, B. Steadman, J. Toth, M. Lee, and J. Azbell, "Probing the Active Site of Yeast Alcohol Dehydrogenase through Microscale Yeast-Mediated Reductions of Acetophenone and Acetylpyridines. A Collaborative and Research-Based Advanced Bioorganic Chemistry Laboratory Project," J. Chem. Educ., vol. 77 , no. 3, p. 363, Mar. 2000.

[32] A. Khalid, "Systems Engineering Graduate Research as Part of Curriculum - Summary of Research," in Conference on Systems Engineering Research (CSER' 13), 2013, vol. 16, pp. 967-975.

[33] N. McKenzie, J. McNulty, D. McLeod, M. McFadden, and N. Balachandran, "Synthesizing Novel Anthraquinone Natural Product-like Compounds To Investigate Protein-Ligand Interactions in Both an in Vitro and in Vivo Assay: An Integrated Research-Based Third-Year Chemical Biology Laboratory Course," J. Chem. Educ., vol. 89, no. 6, pp. 743-749, May 2012.

[34] M. R. Dintzner, J. J. Maresh, C. R. Kinzie, A. F. Arena, and T. Speltz, "A Research-Based Undergraduate Organic Laboratory Project: Investigation of a One-Pot, Multicomponent, Environmentally Friendly Prins-Friedel-Crafts-Type Reaction," J. Chem. Educ., vol. 89, no. 2, pp. 265-267, Jan. 2012.

[35] "Mechanical Characterization of Sn and Shape Memory Alloy InTI Nanowires as Part of an Undergraduate Research Experience," in 2012 ASEE Annual Conference \& Exposition, 2012.

[36] N. Robson and J. A. Morgan, "Introducing Faculty Research to Undergraduate Engineering Students: Enhancing Active Cooperative Learning," in 2012 ASEE Annual Conference \& Exposition, 2012, p. 25.841.1-25.841.9.

[37] W. Walter, "Experience Teaching a Graduate Research Methods Course," in 2012 ASEE Annual Conference \& Exposition, 2012.

[38] I. Makarevitch and E. Kralich, "Mapping maize genes: a series of research-based laboratory exercises.," Biochem. Mol. Biol. Educ., vol. 39, no. 5, pp. 375-83, 2011.

[39] C. D. Jones, "The Kitchen Is Your Laboratory: A Research-Based Term-Paper Assignment in a Science Writing Course," J. Chem. Educ., vol. 88, no. 8, pp. 1062-1068, Aug. 2011.

[40] K. Knutson, J. Smith, M. A. Wallert, and J. J. Provost, "Bringing the excitement and motivation of research to students; Using inquiry and research-based learning in a year-long biochemistry laboratory," Biochem. Mol. Biol. Educ., vol. 38, no. 5, pp. 317-323, Sep. 2010.

[41] F. Goldberg, V. Otero, and S. Robinson, "Design principles for effective physics instruction: A case from physics and everyday thinking," Am. J. Phys., vol. 78, no. 12, p. 1265, 2010.

[42] N. Grover, "Introductory course based on a single problem: Learning nucleic acid biochemistry from AIDS research," Biochem. Mol. Biol. Educ., vol. 32, no. 6, pp. 367-372, Nov. 2004.

[43] W. M. Halalu and A. S. Elwakil, "Research-Oriented Junior/Senior Design Projects: An Analog Circuit Design Example," IEEE Trans. Educ., vol. 47, no. 1, pp. 93-99, Feb. 2004.

[44] E. A. Wiley and N. A. Stover, "Immediate Dissemination of Student Discoveries to a Model Organism Database Enhances Classroom-Based Research Experiences," Cell Biol. Educ., vol. 13, no. 1, pp. 131-138, Mar. 2014.

[45] C. B. Russell and G. C. Weaver, "A comparative study of traditional, inquiry-based, and research-based laboratory curricula: impacts on understanding of the nature of science," Chem. Educ. Res. Pr., vol. 12, no. 1, pp. 57-67, 2011.

[46] E. Seymour, A.-B. Hunter, S. L. Laursen, and T. DeAntoni, "Establishing the benefits of research experiences for undergraduates in the sciences: First findings from a three-year study," Sci. Educ., vol. 88, no. 4, pp. 493-534, Jul. 2004.

[47] K. E. Cole, M. Inada, A. M. Smith, and M. P. Haaf, "Implementing a Grant Proposal Writing Exercise in Undergraduate Science Courses To Incorporate Real-World Applications and Critical Analysis of Current Literature," J. Chem. Educ., vol. 90, no. 10, pp. 1316-1319, Oct. 
2013.

[48] K. Forest and S. Rayne, "Incorporating Primary literature summary projects into a first-year chemistry curriculum," J. Chem. Educ., vol. 86, no. 5, pp. 592-594, 2009.

[49] G. J. Gallagher and D. L. Adams, "Introduction to the Use of Primary Organic Chemistry Literature in an Honors Sophomore-Level Organic Chemistry Course," J. Chem. Educ., vol. 79, no. 11 , p. 1368 , Nov. 2002.

[50] L. Roecker, "Introducing Students to the Scientific Literature," J. Chem. Educ., vol. 84, no. 8, p. 1380, Aug. 2007.

[51] N. E. Lee, R. Gurney, and L. Soltzberg, "Using Green Chemistry Principles As a Framework To Incorporate Research into the Organic Laboratory Curriculum," J. Chem. Educ., vol. 91, no. 7, pp. 1001-1008, Jul. 2014.

[52] M. Lou Caspers and E. S. Roberts-Kirchhoff, "An undergraduate biochemistry laboratory course with an emphasis on a research experience," Biochem. Mol. Biol. Educ., vol. 31, no. 5, pp. 303-307, Sep. 2003.

[53] T. Lord and T. Lord, "Moving from Didactic to Inquiry-Based Instruction in a Science Laboratory," Am. Biol. Teach., vol. 68, no. 6, pp. 342-345, Aug. 2006.

[54] S. G. Hoskins, D. Lopatto, and L. M. Stevens, "The C.R.E.A.T.E. approach to primary literature shifts undergraduates' self-assessed ability to read and analyze journal articles, attitudes about science, and epistemological beliefs.," CBE Life Sci. Educ., vol. 10, no. 4, pp. 368-78, 2011.

[55] J. R. Ford, C. Prudenté, and T. A. Newton, "A Model for Incorporating Research into the FirstYear Chemistry Curriculum," J. Chem. Educ., vol. 85, no. 7, p. 929, Jul. 2008.

[56] M. Harrison, D. Dunbar, L. Ratmansky, K. Boyd, and D. Lopatto, "Classroom-based science research at the introductory level: changes in career choices and attitude.," CBE Life Sci. Educ., vol. 10, no. 3, pp. 279-86, 2011.

[57] S. M. DiBartolomeis and J. P. Moné, "Apoptosis: a four-week laboratory investigation for advanced molecular and cellular biology students.," Cell Biol. Educ., vol. 2, no. 4, pp. 275-95, 2003.

[58] S. Ramos Goyette and J. DeLuca, "A semester-long student-directed research project involving enzyme immunoassay: appropriate for immunology, endocrinology, or neuroscience courses.," CBE Life Sci. Educ., vol. 6, no. 4, pp. 332-42, 2007.

[59] D. R. Howard and J. A. Miskowski, "Using a module-based laboratory to incorporate inquiry into a large cell biology course.," Cell Biol. Educ., vol. 4, no. 3, pp. 249-60, 2005.

[60] M. J. Myers and A. B. Burgess, "Inquiry-based laboratory course improves students' ability to design experiments and interpret data.," Adv. Physiol. Educ., vol. 27, no. 1-4, pp. 26-33, Dec. 2003.

[61] S. K. DebBurman, "Learning how scientists work: experiential research projects to promote cell biology learning and scientific process skills.," Cell Biol. Educ., vol. 1, no. 4, pp. 154-72, 2002.

[62] D. J. Treacy, S. M. Sankaran, S. Gordon-Messer, D. Saly, R. Miller, S. R. Isaac, and M. S. Kosinski-Collins, "Implementation of a project-based molecular biology laboratory emphasizing protein structure-function relationships in a large introductory biology laboratory course.," CBE Life Sci. Educ., vol. 10, no. 1, pp. 18-24, 2011.

[63] P. J. Beuning, "Research skills and ethics: the 20-year evolution of a professional development graduate course," Anal. Bioanal. Chem., pp. 1-4, Oct. 2016.

[64] P. Kneale and A. Edwards-Jones, "Evaluating undergraduate research conferences as vehicles for novice researcher development," Int. J. Res. Dev., vol. 7, no. 2, pp. 159-177, 2016.

[65] C. Schofield and F. L. Burton, "An investigation into higher education student and lecturer views on research publication and their interest in the production of a college partnership science journal," Innov. Educ. Teach. Int., vol. 52, no. 3, pp. 265-276, Jun. 2013.

[66] M. Guron, J. J. Paul, and M. H. Roeder, "Incorporating Sustainability and Life Cycle Assessment into First-Year Inorganic Chemistry Major Laboratories," J. Chem. Educ., vol. 93, no. 4, pp. 639-644, Apr. 2016.

[67] D. Ifenthaler and M. Gosper, "Research-Based Learning: Connecting Research and Instruction," in Curriculum Models for the 21st Century, New York, NY: Springer New York, 2014, pp. 73-89.

[68] C. Guerin and D. Ranasinghe, "Why I Wanted More: Inspirational Experiences of the Teaching-Research Nexus for Engineering Undergraduates," J. Univ. Teach. Learn. Pract., vol. 7, no. 2, 2010.

[69] A. Brew, "Understanding the scope of undergraduate research: a framework for curricular and pedagogical decision-making," High. Educ., vol. 66, no. 5, pp. 603-618, Nov. 2013.

[70] A. Feldman, K. A. Divoll, and A. Rogan-Klyve, "Becoming Researchers: The Participation of 
Undergraduate and Graduate Students in Scientific Research Groups," Sci. Educ., vol. 97, no. 2, pp. 218-243, Mar. 2013. 